\title{
Impacts of Small-Scale Water Management Interventions on Crop Yield, Water Use and Productivity in Two Agro-Ecologies of Malawi
}

\author{
Davie M. Kadyampakeni ${ }^{12^{*}}$, Samson Kazombo-Phiri ${ }^{3}$, Bancy Mati ${ }^{4}$, Isaac R. Fandika1 \\ ${ }^{1}$ Kasinthula Research Station, Chikhwawa, Malawi \\ ${ }^{2}$ University of Florida, Immokalee, USA \\ ${ }^{3}$ Chitedze Agricultural Research Station, Lilongwe, Malawi \\ ${ }^{4}$ Jomo Kenyatta University of Agriculture and Technology, Nairobi, Kenya \\ Email: dakadyampakeni@yahoo.com
}

Received 8 February 2014; revised 23 March 2014; accepted 6 April 2014

Copyright (C) 2014 by authors and Scientific Research Publishing Inc.

This work is licensed under the Creative Commons Attribution International License (CC BY). http://creativecommons.org/licenses/by/4.0/

(c) (i) Open Access

\begin{abstract}
A study was conducted in Malawi to compare the performance of improved agricultural water management interventions with traditional water management practices to assess the impact of the interventions on crop yield and water use productivity. The study used questionnaires and focused group discussions to collect data from farmers and key informants. The results showed significant gains in crop yield, farmer income, and water use productivity using the regulated surface irrigation compared with unregulated surface irrigation. Treadle pump irrigation increased crop production by $5 \%-54 \%$ compared with water can irrigation. Treadle pumps also increased gross and net incomes by $>12 \%$ suggesting that farmers using the treadle pump were able to realize higher incomes across all crop enterprises compared with farmers using water cans. However, there is a dire need to improve the efficiency of the surface irrigation systems for rice production because the water applied was about 2 to 3 times the gross irrigation requirement $\left(\sim 10,780 \mathrm{~m}^{3} \cdot \mathrm{ha}^{-1}\right)$ which could result in environmental degradation through increased salinity and water logging.
\end{abstract}

\section{Keywords}

Irrigation, Smallholder Agriculture, Streamflow Diversion, Water-Use Efficiency

\footnotetext{
*Corresponding author.
}

How to cite this paper: Kadyampakeni, D.M., et al. (2014) Impacts of Small-Scale Water Management Interventions on Crop Yield, Water Use and Productivity in Two Agro-Ecologies of Malawi. Agricultural Sciences, 5, 454-465. 


\section{Introduction}

Agricultural water management has gained enormous attention in the developing world to alleviate poverty, reduce hunger and conserve ecosystems in small-scale production systems of resource-poor farmers [1]-[3]. Interventions range from use of small-scale micro-irrigation systems [4]-[7], gravity-fed and pump-based surface irrigation systems [8] [9], water cans/buckets [9] [10] and rainwater harvesting [6] [11]-[17].

Thus, the Malawi Government, with support from several funding agencies, has scaled-up efforts in increasing access and use of improved water management and irrigation practices to increase food production. The agricultural water management practices/technologies being promoted have largely been gravity-fed surface irrigation systems and treadle pumps in areas with suitable terrain, ample water supply and good soil characteristics. The small-scale gravity-fed surface irrigation systems are large schemes (ranging from 10 to 1000 ha in size) that draw water from perennial rivers into small plots ( 0.1 - $0.2 \mathrm{ha})$ of individual farmers.

The treadle pump is a simple, low-cost pump that is now available in Malawi. The treadle pump was being promoted for adoption by smallholder farmers owing to its simplicity. Much of the repair and maintenance are done by farmers themselves or by a village pump contractor using locally available materials [18]. The treadle pump is ideal for small areas (up to 0.4 ha) which suits well with the landholding size of Malawi [19]-[22]. The treadle pump is appropriate where there are low pumping heads $(<7 \mathrm{~m})$ and short distance to the water source $(<200 \mathrm{~m})$. Impediments to their rapid adoption include complex labour demand and lack of ready markets for agricultural produce [23]-[25]. The irrigation methods commonly used with treadle pumps in Malawi are basin and furrow irrigation [22].

However, poorly documented informal irrigation systems such as streambank gardens (locally called dimbas) [26] and water cans [22] are also in use among small-scale farmers in many parts of Malawi. Despite the interventions in agricultural water management in Malawi, only about $14 \%-20 \%$ of the potential irrigable land, estimated to be $\sim 0.5$ million ha, is under formal irrigation [25] [27]. The information regarding the performance of improved water management technologies vs. traditional practices is lacking for making economically and environmentally sound policy decisions. Researchers [28] proposed the irrigation efficiency and profit maximization as key indicators for assessing the performance of water management systems. Placing emphasis on increasing water-use efficiency in small-scale irrigation systems [29] would reduce competing water uses between upstream vs. downstream water users [30], and agricultural vs. domestic water consumption [2] [8].

The case study aimed to 1) compare the crop performance, water use productivity and net incomes of regulated surface irrigation (RSI) with unregulated surface irrigation (USI); and 2) determine the effect of treadle pumps on crop production, labour use, water use productivity and incomes among small-scale farmers. The findings are critical for improving interventions and investments in agricultural water management and for sustaining environmental quality in developing countries.

\section{Materials and Methods}

\subsection{Site Characteristics}

The studies were conducted in March through August 2007 at the two sites: Domasi and Tembwe Extension Planning Areas in southern and central Malawi, representing sites for gravity fed surface irrigation and treadle pump surface irrigation, respectively (Table 1). The sites were chosen because the Malawi Government, with support from funding agencies, chose these sites for $\sim 3$ year interventions in irrigation and agricultural development.

\subsection{Estimation of Water Use and Irrigation Rates}

The average crop water consumptive use $\left(\mathrm{ET}_{\mathrm{c}} \mathrm{in} \cdot \mathrm{mm} \cdot \mathrm{d}^{-1}\right)$ was computed by the FAO CROPWAT on daily basis [31] using the climatic data from Chileka International Airport (Table 2) due to lack of weather stations from the study sites.

Using the same CROPWAT programme, we estimated what should have been appropriate net irrigation, gross irrigation and seasonal irrigation requirement for the two sites (Table 3).

Irrigation efficiency and water use productivity were also estimated according to [32]. The expression for estimating irrigation efficiency is given as:

$$
\mathrm{IE}=\mathrm{ET}_{\mathrm{c}} / \mathrm{WA}
$$


D. M. Kadyampakeni et al.

Table 1. Site characteristics of the two study sites of Malawi.

\begin{tabular}{|c|c|c|c|c|c|c|c|c|c|c|}
\hline District & ${ }^{1} \mathrm{EPA}$ & $\begin{array}{l}\text { Latitude/ } \\
\text { Longitude }\end{array}$ & $\begin{array}{l}\text { Altitude } \\
\left({ }^{2} \text { masl }\right)\end{array}$ & $\begin{array}{l}\text { Annual } \\
\text { rainfall } \\
(\mathrm{mm})\end{array}$ & $\begin{array}{l}\text { Soil } \\
\text { order }\end{array}$ & $\begin{array}{l}\text { Soil } \\
\text { texture }\end{array}$ & $\begin{array}{c}\text { Number of } \\
\text { farmers }\end{array}$ & $\begin{array}{c}\text { Area for } \\
\text { irrigated } \\
\text { production (ha) }\end{array}$ & Crops & Technology \\
\hline Machinga & Domasi & $\begin{array}{l}15^{\circ} 19^{\prime} \mathrm{S} / \\
35^{\circ} 24^{\prime} \mathrm{E}\end{array}$ & 800 & 900 & Latosol & Clay loam & 1556 & 500 & $\begin{array}{l}\text { Rice, maize, } \\
\text { wheat }\end{array}$ & $\begin{array}{l}\text { Gravity surface } \\
\text { irrigation }\end{array}$ \\
\hline Mchinji & Tembwe & $\begin{array}{l}13^{\circ} 47^{\prime} \mathrm{S} / \\
32^{\circ} 58^{\prime} \mathrm{E}\end{array}$ & 1100 & 1200 & Latosol & Clay loam & 350 & 120 & $\begin{array}{l}\text { Bean, maize, } \\
\text { cabbage, onion }\end{array}$ & $\begin{array}{l}\text { Surface irrigation } \\
\text { by treadle pump } \\
\text { and overhead } \\
\text { irrigation using } \\
\text { water can }\end{array}$ \\
\hline
\end{tabular}

${ }^{1}$ Extension planning area; ${ }^{2}$ Masl-metres above sea level.

Table 2. Average climatic characteristics of Malawi (sourced from Chileka International Airport).

\begin{tabular}{ccccccccc}
\hline Month & Minimum temperature & Maximum temperature & Humidity & Wind & Sunshine & \multicolumn{2}{c}{ Radiation } & ${ }^{1} \mathrm{ET}_{\mathrm{o}}$ \\
\hline January & ${ }^{\circ} \mathrm{C}$ & ${ }^{\circ} \mathrm{C}$ & $\%$ & $\mathrm{~km} \cdot \mathrm{d}^{-1}$ & $\mathrm{~h}$ & $\mathrm{MJ} \mathrm{m}^{-2 \cdot} \cdot \mathrm{d}^{-1}$ & ${\mathrm{~mm} \cdot \mathrm{d}^{-1}}^{2}$ \\
February & 20.1 & 28.4 & 79 & 233 & 6 & 19.9 & 4.41 \\
March & 19.9 & 28.3 & 80 & 233 & 6.1 & 19.7 & 4.30 \\
April & 19.3 & 27.8 & 78 & 259 & 6.1 & 18.6 & 4.17 \\
May & 17.9 & 27.2 & 75 & 285 & 7.4 & 18.6 & 4.17 \\
June & 15.6 & 25.9 & 69 & 294 & 7.5 & 16.6 & 3.94 \\
July & 13.6 & 24.1 & 66 & 294 & 6.7 & 14.6 & 3.57 \\
August & 13.3 & 23.9 & 64 & 302 & 6.9 & 15.3 & 3.72 \\
September & 14.5 & 26.1 & 50 & 328 & 7.4 & 17.7 & 5.10 \\
October & 17.1 & 29.2 & 52 & 354 & 7.7 & 20.2 & 6.04 \\
November & 19.5 & 31.3 & 53 & 346 & 8.1 & 22.3 & 6.72 \\
December & 20.3 & 30.7 & 61 & 302 & 7.1 & 21.4 & 5.97 \\
Average & 20.2 & 29.2 & 75 & 268 & 6.1 & 20.0 & 4.78 \\
\hline
\end{tabular}

${ }^{1} \mathrm{ET}_{0}$ - Reference evapotranspiration.

Table 3. Crop growth development stages used to estimate net irrigation, gross irrigation and water use using CROPWAT 8.0 basing on climatic data from Chileka weather station.

\begin{tabular}{cccccc}
\hline Crop & \multicolumn{5}{c}{ Length of growing season } \\
\hline Cabbage & Initial stage & Development stage & Mid-season stage & Late season stage & Total days \\
Onion & 35 & 45 & 40 & 15 & 135 \\
Beans & 25 & 30 & 40 & 15 & 110 \\
Wheat & 20 & 30 & 40 & 20 & 110 \\
Maize & 15 & 30 & 65 & 40 & 150 \\
Rice & 30 & 40 & 60 & 10 & 140 \\
\hline Cabbage & 0.70 & Crop coefficient $\left(\mathrm{K}_{\mathrm{c}}\right)$ by stage & 30 & 150 \\
Onion & 0.70 & 1.05 & 1.05 & 0.95 & 0.40 \\
Beans & 0.50 & 1.00 & 1.05 & 0.75 & 0.30 \\
Wheat & 0.30 & 1.05 & 1.05 & 0.90 & 0.40 \\
Maize & 0.70 & 1.15 & 1.15 & 0.40 & 1.00 \\
Rice & 1.05 & 1.15 & 1.15 & 1.05 & 1.50 \\
\hline
\end{tabular}


where IE = irrigation efficiency $\left(\mathrm{m}^{3} \cdot \mathrm{m}^{-3}\right), \mathrm{ET}_{\mathrm{c}}=$ crop evapotranspiration $\left(\mathrm{m}^{3}\right)$, WA $=$ water applied $\left(\mathrm{m}^{3}\right)$

$$
\mathrm{WUP}=\mathrm{Y} / \mathrm{ET}_{\mathrm{c}}
$$

where WUP = water use productivity $\left(\mathrm{kg} \cdot \mathrm{m}^{-3}\right), \mathrm{Y}=$ yield $\left(\mathrm{kg} \cdot \mathrm{ha}^{-1}\right), \mathrm{ET}_{\mathrm{c}}=$ crop evapotranspiration $\left(\mathrm{m}^{3}\right), \mathrm{WA}=$ water applied $\left(\mathrm{m}^{3}\right)$

Net irrigation was calculated for clay loam soil using an approximate irrigation schedule in CROPWAT 8.0 and an appropriate gross irrigation requirement was estimated assuming $70 \%$ irrigation efficiency as:

$$
\text { GIRR }=\text { NIRR/IE }
$$

where GIRR = gross irrigation $\left(\mathrm{m}^{3}\right), \mathrm{NIRR}=$ net irrigation $\left(\mathrm{m}^{3}\right)$ and $\mathrm{IE}=$ irrigation efficiency expressed as a fraction.

\subsection{Sampling Design}

\subsubsection{Site 1: The Domasi Irrigation Scheme}

In this study, field data collection involved questionnaire interviews with household heads and focused group discussions. A total of 60 households were interviewed in questionnaire surveys. This sample was divided into two categories. The first group of 30 were farmers using well-controlled border and furrow surface irrigation at Domasi Irrigation Scheme. The latter half constituted farmers cultivating streambanks and relying on seepage and water from nearby streams, albeit, without proper water diversion channels as their counterparts in the scheme. Quantitative and socio-economic data were obtained from observations through questionnaire interviews with the smallholder farmers and data provided by extension staff. The types of data collected included: crop yields, costs of labour and inputs, rainfall and farm gate prices of major crops. Other quantitative data such as irrigation scheduling and duration (to estimate water volumes) and socio-economic indicators were obtained from agricultural extension development coordinators and other key informants. The data on gross revenue and prices had been converted into US dollar (\$) equivalent based on the prevailing exchange rate at the time of the study $(\$ 1.00=$ MWK140.90).

\subsubsection{Site 2: The Mchinji Site}

A total of 60 households were interviewed at Tembwe Extension Planning Area. This sample was also divided into two: a group of 30 farmers who used treadle pumps for irrigation and the other 30 who used the traditional water can irrigation technology. The two groups provided comparative data used to indicate the added value of the treadle pumps to smallholder irrigated agriculture. Supplementary information was obtained from agricultural extension development coordinators and other local leaders. Data collected included: crop yields $\left(\mathrm{kg} \cdot \mathrm{ha}^{-1}\right)$, number of irrigations and irrigation durations to estimate amount of water applied for two technologies, labour and input costs $(\$)$, farm gate prices $\left(\$ \cdot \mathrm{kg}^{-1}\right)$. All costs and yields were estimated per ha to quantify the benefits of the technology to the farmer.

\subsection{Data Analysis}

The field data were analyzed using the SPSS version 12.0 to enumerate the performance of each the technology. Gross margin analysis was performed to determine the performance of each system of water management. Gross incomes were calculated by:

$$
\mathrm{R}=\mathrm{Y} * \mathrm{Py}
$$

where

$$
\begin{aligned}
& \mathrm{R}=\text { Revenue }\left(\$ \cdot \mathrm{ha}^{-1}\right) ; \\
& \mathrm{Y}=\text { Yield }\left(\mathrm{kg} \cdot \mathrm{ha}^{-1}\right) ; \\
& \text { Py = Price of the crop per unit }\left(\$ \cdot \mathrm{kg}^{-1}\right) \text {. }
\end{aligned}
$$

Net returns were estimated from the following expression:

$$
\mathrm{NR}=\mathrm{R}-\mathrm{TVC}
$$

$\mathrm{NR}=$ Net return $\left(\$ \cdot h \mathrm{~h}^{-1}\right)$;

$$
\mathrm{R}=\text { Revenue }\left(\$ \cdot h a^{-1}\right) \text {; }
$$


TVC $=$ Total variable costs $\left(\$ \cdot h a^{-1}\right)$.

\section{Results}

\subsection{Performance of Regulated and Unregulated Surface Irrigation}

The added value of regulated surface irrigation (RSI) was quite evident from the crop yields achieved, as shown in Figure 1. Under RSI, the yields of maize were four times greater than the yields realized using unregulated surface irrigation. Rice yields realized using RSI $\left(3.60 \mathrm{t} \cdot \mathrm{ha}^{-1}\right)$ were threefold greater than that of the unregulated surface irrigation (USI). Yields of wheat with RSI were higher by $59 \%$ over unregulated surface irrigation. Generally, gross incomes were higher with RSI than USI for all the three crops.

But the net incomes for all three enterprises showed significant advantage of RSI compared with unregulated surface irrigation. The net income realized for maize, wheat and rice were $\$ 322 \mathrm{ha}^{-1}$, \$162 ha ${ }^{-1}$ and $\$ 1184 \mathrm{ha}^{-1}$, respectively under regulated surface irrigation (Table 4). This represents a significant improvement on incomes by factors of $636 \%, 128 \%$ and $377 \%$, respectively over the USI. It should be noted that maize grown under USI attained a negative net income $\left(-\$ 60 \mathrm{ha}^{-1}\right)$. Similar results were reported by [33] in the Kaiti catchment of Kenya where negative net incomes were obtained for practices without improved water management. These findings explain the reasons for rural poverty and why poverty preference indices are high among subsistence smallholder farmers growing maize because farmers choose crop enterprises based on yields. Maize has low monetary value, and thus usually has the lowest returns on land put under production. Another reason could be ascribed to the limited access and use of streambanks of Domasi River and wetland gardens [26] [34] [35]. Use of the streambanks and wetland gardens could in the long-term affect ecological and environmental sustainability. It appears farmers using USI in the nearby wetlands have constraints regarding water management and sustainable agricultural production, due to lack of water control and application structures.

The irrigation efficiency showed that water applied was adequate for wheat and maize under RSI. The maize and wheat grown under USI was water stressed, resulting in significantly lower yields than those using RSI. The irrigation efficiency for rice was very low $~ 0.28$ - 0.40, for both RSI and USI, suggesting over-irrigation which probably resulted into water logging and excessive nutrient leaching. For example, the water applied in the rice fields was about 2 to 3 times more than the gross irrigation requirement $\left(\sim 10,780 \mathrm{~m}^{3} \cdot \mathrm{ha}^{-1}\right)$. This was somewhat surprising particularly for the farmers using RSI because it was presumed they had received some training on irrigation management. This reveals an important aspect in the water management endeavours of small-scale rice farmers because there is lack of sound water management and water control. At Domasi Irrigation Scheme, there are no clear structures for measuring the amount of water applied per plot. Each farmer applies water according

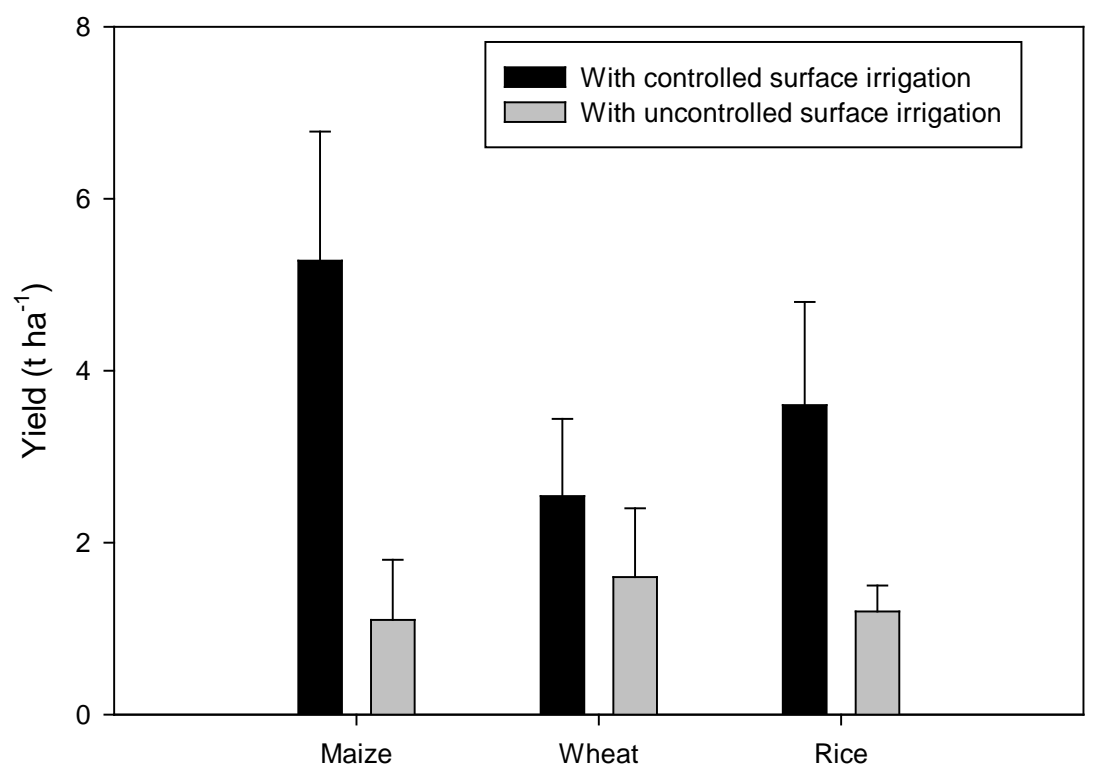

Figure 1. Yield of maize, rice and wheat at domasi irrigation scheme. 
Table 4. Performance of regulated and unregulated surface irrigation: water use, irrigation efficiency, water productivity and value of produce per unit of water.

\begin{tabular}{|c|c|c|c|c|c|c|}
\hline Irrigation practice/Crop & Wheat & Maize & Rice & Wheat & Maize & Rice \\
\hline & \multicolumn{3}{|c|}{ Border/Furrow (regulated) } & \multicolumn{3}{|c|}{ Border/Furrow (unregulated) } \\
\hline Net irrigation $\left(\mathrm{m}^{3}\right)$ & 5820.0 & 6000.0 & 7540.0 & 5820.0 & 6000.0 & 7540.0 \\
\hline Gross irrigation $\left(\mathrm{m}^{3}\right)$ & 8310.0 & 8570.0 & 10780.0 & 8310.0 & 8570.0 & 10780.0 \\
\hline Water used $\left(\mathrm{m}^{3}\right)$ & 6352.0 & 6667.0 & 8173.0 & 6352.0 & 6667.0 & 8173.0 \\
\hline Water applied $\left(\mathrm{m}^{3}\right)$ & 7247.8 & 6698.0 & 28900.0 & 3018.9 & 5650.0 & 20210.0 \\
\hline Irrigation efficiency $\left(\mathrm{m}^{3} \cdot \mathrm{m}^{-3}\right)$ & 0.88 & 1.00 & 0.28 & 2.10 & 1.18 & 0.40 \\
\hline WUP $\left(\mathrm{kg} \cdot \mathrm{m}^{-3}\right)$ & 0.40 & 0.79 & 0.44 & 0.25 & 0.16 & 0.15 \\
\hline Revenue at farm gate price (US\$ ha-1) & 330.0 & 528.0 & 1404.0 & 208.0 & 110.0 & 468.0 \\
\hline Revenue per unit of water used (US\$ $\mathrm{m}^{-3}$ ) & 0.05 & 0.08 & 0.17 & 0.02 & 0.03 & 0.06 \\
\hline $\mathrm{NR}\left(\$ \mathrm{ha}^{-1}\right)$ & 162 & 321 & 1184 & 71 & -60 & 248 \\
\hline
\end{tabular}

CROPWAT 8.0 used for estimating gross irrigation requirement, net irrigation and water use; WUP—Water use productivity $\left(\mathrm{kg} \cdot \mathrm{m}^{-3}\right)$; NI—Net return $\left(\$ \cdot \mathrm{m}^{-3}\right)$.

to a set schedule, not necessarily according to irrigation need. This tends to encourage the farmers to over-irrigate in rice systems using either RSI or USI. There was higher water use productivity (WUP) using RSI (0.40 0.79) compared with those using USI (0.15 - 0.25).

\subsection{Performance of Treadle Pumps vs. Water Can in Improving Crop Productivity and Water Use}

Generally, there was added value by using treadle pumps over water can. Farmers using treadle pump irrigation realized increased production of beans and maize by 34\% and 54\%, respectively, compared with water can irrigation. However, the yield gains for cabbage and onion with treadle pump irrigation were marginal $14 \%$ and $5 \%$, respectively (Figure 2). Our results do not clearly show benefits between treadle pump and water can with regard to yield for beans, cabbage and onion. These findings agree with those from other districts of Malawi for beans, onion and [7] [9] [18] [36]. However, the yields of cabbage, maize and beans for farmers who had used water can irrigation agree with those reported for similar agro-ecologies in Ntcheu, Dedza and Lilongwe districts of central Malawi [37]-[39]. The farmers using treadle pumps were able to pump more water per unit time $\left(1.6 \mathrm{~L} \cdot \mathrm{s}^{-1}\right)$ as opposed to water can irrigation, which has a volume of $10 \mathrm{~L}$. The bucket may take the farmer(s) about twice to thrice the time required to irrigate an area using a treadle pump [9]. Thus, a farmer using a treadle pump requires less labour to irrigate a unit area compared with a water can. It is evident that the treadle pump improved the efficiency of irrigation by saving time and labour. Farmers who do not have treadle pumps are at a disadvantage because they tend to irrigate when labour is available and not necessarily when the crop needs water at any critical growth stage.

\subsection{Scope for Improving Farm Incomes Using Treadle Pumps and Water Cans}

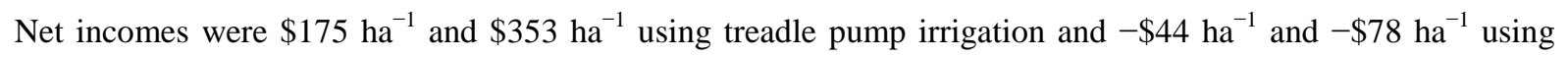
water cans for beans and maize, respectively (Table 5). This difference could be due to their different water requirements, yield potentials and market prices. However, net incomes using treadle pumps for cabbage and onion increased by $96 \%$ and $12 \%$ over yields realized with water can irrigation. The marginal increase for onions was attributed to the fact that onions are grown generally on smaller plots and thus, are easily irrigated with water cans making the added value of treadle pump less evident. On the contrary, treadle pumps enabled irrigation of larger areas of maize and beans.

Farmers using the water can incurred more labour costs compared with treadle pump users because of the need for hired labour. Generally, water sources were situated about $30 \mathrm{~m}$ to $120 \mathrm{~m}$ from irrigated fields and this 


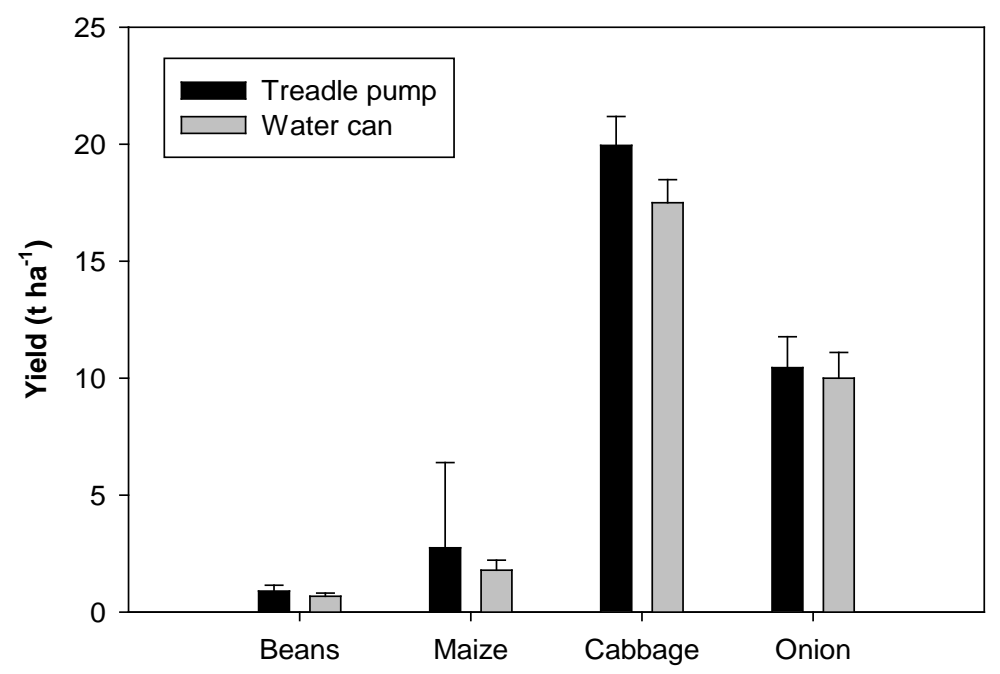

Figure 2. Crop yields for treadle pump and water can irrigation in Mchinji district.

Table 5. Performance of treadle pump and water can irrigation technologies: water use, irrigation efficiency, water productivity and value of produce per unit of water.

\begin{tabular}{|c|c|c|c|c|c|c|c|c|}
\hline Crop & Cabbage & Onion & Beans & Maize & Cabbage & Onion & Beans & Maize \\
\hline Irrigation practice & \multicolumn{4}{|c|}{ Treadle pump } & \multicolumn{4}{|c|}{ Water can } \\
\hline Net irrigation $\left(\mathrm{m}^{3}\right)$ & 5200 & 4136 & 4154 & 6002 & 5200 & 4136 & 4154 & 6002 \\
\hline Gross irrigation $\left(\mathrm{m}^{3}\right)$ & 7434 & 5909 & 5953 & 8570 & 7434 & 5909 & 5953 & 8570 \\
\hline Water used $\left(\mathrm{m}^{3}\right)$ & 5740 & 4665 & 4743 & 6660 & 5740 & 4665 & 4743 & 6660 \\
\hline Water applied $\left(\mathrm{m}^{3}\right)$ & 4850 & 6440 & 5720 & 6010 & 3460 & 4490 & 4920 & 4810 \\
\hline Irrigation efficiency $\left(\mathrm{m}^{3} \cdot \mathrm{m}^{-3}\right)$ & 1.18 & 0.72 & 0.83 & 1.11 & 1.66 & 1.04 & 0.96 & 1.38 \\
\hline${ }^{1}$ WUP $\left(\mathrm{kg} \cdot \mathrm{m}^{-3}\right)$ & 3.48 & 2.24 & 0.19 & 0.41 & 3.06 & 2.12 & 0.14 & 0.27 \\
\hline Revenue at farm gate price $\left(\mathrm{US} \$ \cdot \mathrm{ha}^{-1}\right.$ ) & 1400 & 1463 & 495 & 907 & 1225 & 1401 & 369 & 589 \\
\hline Revenue per unit of water used (US\$ $\cdot \mathrm{m}^{-3}$ ) & 0.24 & 0.31 & 0.10 & 0.14 & 0.21 & 0.30 & 0.08 & 0.09 \\
\hline${ }^{2} \mathrm{NR}\left(\mathrm{US} \$ \cdot \mathrm{ha}^{-1}\right)$ & 651.0 & 701.0 & 175.0 & 353.0 & 332.5 & 626.5 & -44.0 & -78.0 \\
\hline
\end{tabular}

CROPWAT 8.0 used for estimating gross irrigation requirement, net irrigation and water use; WUP—Water use productivity $\left(\mathrm{kg} \cdot \mathrm{m}^{-3}\right)$; NI—Net return $\left(\$ \cdot \mathrm{m}^{-3}\right)$.

discouraged farmers from irrigating crops like maize and beans using water cans because beans do not attract high prices at local markets. The study showed that incremental benefits on crop yield were achieved by adopting treadle pumps, thereby increasing the yields for beans, onion, maize and cabbage. Also, treadle pumps increased gross and net incomes by $>12 \%$ suggesting that farmers using the treadle pump were able to realize higher incomes across all crop enterprises compared with farmers using water cans.

\section{Discussion}

\subsection{Impacts of the Regulated Surface Irrigation on Crop Yields, Farmer Incomes and Water Use}

These results show that there are positive impacts of RSI, as farms within Domasi Irrigation Scheme showed higher crop yields and net incomes over those using USI, probably due to the reliability of water applications. The farmers using USI depend on river beds to divert water into the maize, wheat and rice fields. Farmers within 
the Domasi Irrigation Scheme were in an organized system and therefore had received formal training in water management from Smallholder Flood Plains Development Project (SFPDP) and the Malawi government departments of agricultural extension and irrigation, unlike their counterparts outside. This training may have facilitated better agronomic practices and water management impacting positively on the crop yields, when compared with those using USI. It has been noted that where water management technologies are adequately handled, the impact of the investments is considerably higher in production, water savings and sustainability [40]. But this is not necessarily the rule because contrasting results were found in South Africa, where $50 \%$ of farmers participating in some selected irrigation schemes were found to have negative returns on investment [41].

Institutional arrangements in irrigation schemes can make a difference and determine whether farmers make a profit or not. For instance, the irrigation management at the schemes described by [41] were poorly managed and not under the full control of the smallholder farmers. At Domasi Irrigation Scheme, a water users' association was formed to ensure equitable sharing of water for irrigation. Despite this, it was noted that the farmers at Domasi had not grasped the concepts of costing water and optimizing water use, particularly in rice production. Traditionally, most farmers in Malawi view water as an infinite resource [9] and a social good that should be supplied free of charge [42]. However, the value of water in smallholder irrigation schemes varies with crop and farmer type [43] calling for ways of teaching the farmers to treat water as a dwindling and scarce resource. Another observation was that farmers utilize border, check basin and furrow irrigation methods which generally have low water productivity. At Domasi Irrigation Scheme, the water used for irrigation is rarely measured, thus many farmers are not aware that they use excessive amounts of water. Moreover, irrigation scheduling is not matched with crop water requirement, resulting in low water use productivity. The low irrigation efficiency particularly under RSI was unexpected and indicated problems with flow regulating devices and structures thereby complicating management, maintenance and sustainability of the irrigation system in the long-term. A similar problem was noted in Likangala Irrigation Scheme in the same agricultural ecological zone by [44] and in several irrigation schemes in Tanzania [28]. Yields and water productivity have also been found to be far below potential in many rice producing regions and significant improvements can be achieved in crop production by sound management of inputs [45] [46]. To improve efficiency in surface irrigation systems, methods of measuring water at farm level need to be introduced as well as more efficient methods of irrigation. For example, [47] showed that water applied by drip was $43 \%$ to $74 \%$ of that applied by surface irrigation. Other studies have also shown that drip-, microsprinkler and well-controlled surface irrigation systems that allow for good water control and nutrient management improved irrigated crop production and water use-efficiency [48]-[50]. Therefore, training farmers to treat water as a scarce and valuable resource would be the first step in helping them manage water efficiently. This is particularly pertinent in rice-based systems because in Domasi, farmers tend to over-irrigate leading to poor drainage, as the water table is within 0.4 to $0.6 \mathrm{~m}$ from the ground surface. For the farmers utilizing streambeds in unregulated irrigation, there is need to plan and implement proper water control and to train farmers on water management so as to improve crop performance and safeguard the environment.

\subsection{Impacts of Treadle Pump Irrigation and Water Can on Crop Yield and Water Use}

The treadle pump users indicated that, given availability of agronomic inputs, the treadle pump can be used for income generation. Overall, this study showed that use of treadle pumps increased crop yield and incomes indicating that the technology can be used for poverty reduction with good success rates. The better gross and net incomes obtained for maize and beans indicate the potential of treadle pumps to boost food security and income. However, the technology is still manually operated, thus it is tiresome and has limitations on the amount of land that can be irrigated in a day. Our results are consistent with observations by [51] who demonstrated that labour availability and increase in irrigated area have a bearing on treadle pump adoption. The results from the treadle pump vs. water can study agree with [52] in West Africa. According to Namara and colleagues, the farmers using such small-scale water extraction technologies from shallow wells, develop complex but water-efficient and labor-intensive on-farm water management and agronomic practices. They also noted that cultivation of the crops, such as tomato and pepper, under shallow groundwater irrigation is generally profitable, particularly when the value of family labor involved in the cultivation process is not considered. Using this line of thinking, cultivation of cabbage and onion were profitable using treadle pump and water can irrigation. Labour costs results in negative net incomes for bean and maize. During the dry season, in sub-Saharan Africa, with one rainy season, land and labour are relatively abundant but water is the limiting factor for production. Such technologies 
create employment for other local farmers, thus helping in reducing rural poverty and contributing to the local economy. Also, the crop harvest in the dry season augments the food security status of rural households using the treadle pump and water can irrigation. In a different study on treadle pumps in Mchinji district, [53] noted serious poverty indices for farmers without treadle pumps. This school of thought by [53] is justified, considering that treadle pump farmers spend less time on irrigation compared with their counterparts using water cans. This study demonstrated that irrigation efficiencies were similar for both systems falling between 0.72 - 1.18 for treadle pump and 0.96 - 1.66 for water can. Water use productivities, however, suggest that cabbage and onion convert water into greater yield $\left(\sim 2-3.5 \mathrm{~kg} \cdot \mathrm{m}^{-3}\right)$ and gross income than maize and beans $\left(0.14-0.41 \mathrm{~kg} \cdot \mathrm{m}^{-3}\right)$. The irrigation applications appear to be adequate though water deficits (from the water use calculations using CROPWAT model) were noted in cabbage and maize calling for improvements in irrigation scheduling and timing. Improvements that could be proposed and have worked elsewhere include use of simple drip irrigation kits powered by treadle pumps or use of fairly large buckets $(>1500 \mathrm{~L})$ that could be filled with water from shallow wells [7] [54] to increase water delivery efficiency per planting station.

\section{Conclusions}

This paper determined the performance of improved vs. traditional water management practices in Malawi. The results showed enormous yield gains using well-managed surface irrigation on rice, maize and wheat production compared with uncontrolled surface irrigation and water management practices. Also, regulated surface irrigation improved farm net incomes. However, it appears that there is a dire need to improve irrigation efficiency in both the regulated and unregulated surface irrigation systems.

Sensitizing farmers to view water as a scarce resource with economic value would help them manage water efficiently, especially in rice-based systems where they tend to over-irrigate leading to poor drainage as shown at Domasi Irrigation scheme. Improvements are needed in water delivery of surface irrigation systems. For the unregulated surface irrigation, it is also necessary to introduce some methods of water control (e.g. flumes, weirs and flow meters) and enact policies that support coordinated activities by farmers while safe-guarding environmental integrity of riparian lands.

The results showed that labour efficiency and delivery of large water volumes per unit time were the major benefits of treadle pumps over water cans and not necessarily irrigation efficiency and crop yield. Thus, the adopters of treadle pumps are likely to be involved in other income generating activities by making use of the time gains from the utilization of the treadle pump.

\section{Acknowledgements}

We are grateful to the Improved Management of Agricultural Water in Eastern and Southern Africa (IMAWESA) project for funding the study and the Malawi Government Ministries of Agriculture and Food Security, and Irrigation and Water Development for facilitating the farmer interviews.

\section{References}

[1] Hanjra, M.A., Ferede, T. and Gutta, D.G. (2009) Pathways to Breaking the Poverty Trap in Ethiopia: Investments in Agricultural Water, Education, and Markets. Agricultural Water Management, 96, 1596-1604. http://dx.doi.org/10.1016/j.agwat.2009.06.008

[2] De Fraiture, C., Molden, D. and Wichelns, D. (2010) Investing in Water for Food, Ecosystems, and Livelihoods: An Overview of the Comprehensive Assessment of Water Management in Agriculture. Agricultural Water Management, 97, 495-501. http://dx.doi.org/10.1016/j.agwat.2009.08.015

[3] Gordon, L.J., Finlayson, C.M. and Falkenmark, M. (2010) Managing Water in Agriculture for Food Production and Other Ecosystem Services. Agricultural Water Management, 97, 512-519. http://dx.doi.org/10.1016/j.agwat.2009.03.017

[4] Kulecho, I.K. and Weatherhead, K. (2006) Issues of Irrigation of Horticultural Crops by Smallholder Farmers in Kenya. Irrigation and Drainage Systems, 20, 259-266. http://dx.doi.org/10.1007/s10795-006-9006-y

[5] Karlberg, L., Rockstrom, J., Annandale, J.G. and Steyn, J.M. (2007) Low-Cost Drip Irrigation-A Suitable Technology for Southern Africa? An Example with Tomatoes Using Saline Irrigation Water. Agricultural Water Management, 89, 59-70. http://dx.doi.org/10.1016/j.agwat.2006.12.011

[6] Molden, D., Oweis, T., Steduto, P., Bindraban, P., Hanjra, M.A. and Kijne, J. (2010) Improving Agricultural Water 
Productivity: Between Optimism and Caution. Agricultural Water Management, 97, 528-535. http://dx.doi.org/10.1016/j.agwat.2009.03.023

[7] Fandika, I.R., Kadyampakeni, D. and Zingore, S. (2012) Performance of Bucket Drip Irrigation by Treadle Pump on Tomato and Maize/Bean Production in Malawi. Irrigation Science, 30, 57-68. http://dx.doi.org/10.1007/s00271-010-0260-2

[8] Komakech, H.C., Mul, M.L., van der Zaag, P. and Rwehumbiza, F.B.R. (2011) Water Allocation and Management in an Emerging Spate Irrigation System in Makanya Catchment, Tanzania. Agricultural Water Management, 98, 17191726. http://dx.doi.org/10.1016/j.agwat.2010.07.017

[9] Kadyampakeni, D.M., Mloza-Banda, H.R., Singa, D.D., Mangisoni, J.H., Ferguson, A. and Snapp, S. (2012) Agronomic and Socio-Economic Analysis of Water Management Techniques for Dry Season Cultivation of Common Bean in Malawi. Irrigation Science, 31, 537-544. http://dx.doi.org/10.1007/s00271-012-0333-5

[10] Pachpute, J.S. (2010) A Package of Water Management Practices for Sustainable Growth and Improved Production of Vegetable Crop in Labour and Water Scarce Sub-Saharan Africa. Agricultural Water Management, 97, 1251-1258. http://dx.doi.org/10.1016/j.agwat.2009.11.009

[11] Wiyo, K.A., Kasomekera, Z.M. and Feyen, J. (2000) Effect of Tied-Ridging on Soil Water Status of a Maize Crop under Malawi Conditions. Agricultural Water Management, 45, 101-125. http://dx.doi.org/10.1016/S0378-3774(99)00103-1

[12] Rockstrom, J., Barron, J. and Fox, P. (2002) Rainwater Management for Increased Productivity among Small-Holder Farmers in Drought Prone Environments. Physics and Chemistry of the Earth, 27, 949-959. http://dx.doi.org/10.1016/S1474-7065(02)00098-0

[13] Jensen, J.R., Bernhard, R.H., Hansen, S., McDonagh, J., Moberg, J.P., Nielsen, N.E. and Nordbo, E. (2003) Productivity in Maize Based Cropping Systems under Various Soil-Water-Nutrient Management Strategies in a Semi-Arid, Alfisol Environment in East Africa. Agricultural Water Management, 59, 217-237. http://dx.doi.org/10.1016/S0378-3774(02)00151-8

[14] Mugabe, F.T., Hodnett, M.G. and Senzanje, A. (2003) Opportunities for Increasing Productive Water Use from Dam Water: A Case Study from Semi-Arid Zimbabwe. Agricultural Water Management, 62, 149-163. http://dx.doi.org/10.1016/S0378-3774(03)00077-5

[15] Mloza-Banda, H. (2006) Experiences with Micro Agricultural Water Management Technologies: Malawi. Report Submitted to the International Water Management Institute (IWMI) Southern Africa Sub-Regional Office Pretoria, South Africa, $27 \mathrm{p}$.

[16] Shemdoe, R.S., Van Damme, P. and Kikula, I.S. (2009) Increasing Crop Yield in Water Scarce Environments Using Locally Available Materials: An Experience from Semi-Arid Areas in Mpwapwa District, Central Tanzania. Agricultural Water Management, 96, 963-968. http://dx.doi.org/10.1016/j.agwat.2009.01.007

[17] Rockströma, J., Karlberg, L., Wani, S.P., Barron, J., Hatibu, N., Oweis, T., Bruggeman, A., Farahani, J. and Qiang, Z. (2010) Managing Water in Rainfed Agriculture-The Need for a Paradigm Shift. Agricultural Water Management, 97, 543-550. http://dx.doi.org/10.1016/j.agwat.2009.09.009

[18] Wiyo, K.A., Lunduka, R.W. and Nalivata, P.C. (2002) Malawi Treadle Pump Impact Assessment Study. Department of Irrigation, Ministry of Agriculture and Irrigation, Lilongwe.

[19] Mzembe, C.P. (1997) Training Manual for the Design of a Field Layout for a Small Scale Irrigation System Fitted with a Treadle Pump. Lilongwe.

[20] Hayes, I.M., Jere, Z.D., Bunderson, W.T., Cornish, G. and Mlozi Banda, M. (2002) Field Manual for Treadle Pump Irrigation in Malawi. Total Landcare (TLC) Malawi Publication No. 1, Lilongwe.

[21] Jere, Z.D. and Bunderson, W.T. (2004) An Extension Approach to Scale-Up Adoption of Small-Scale Irrigation Technology. Lilongwe.

[22] Kadyampakeni, D.M. (2004) Comparative Analysis of Different Irrigation Technologies and Water Management Techniques for Dry Season Cultivation of Beans in Zomba, Malawi. MSc Thesis, Bunda College of Agriculture, University of Malawi, Zomba.

[23] Van Leeuwen, N. (2003) Agriculture and Water Management for Crops. In: Gopal, B., Pathak, P.S., Raman, A. and Lee, S.Y., Eds., Special Issue: Wetlands and Agriculture, International Journal of Ecology and Environmental Sciences, 29, 11-14.

[24] Tindamanyire, T. (2003) Wetlands, Water Resources and Agricultural Productivity: An Important Synergy for Biodiversity Conservation. In: Gopal, B., Pathak, P.S., Raman, A. and Lee, S.Y., Eds., Special Issue: Wetlands and Agriculture, International Journal of Ecology and Environmental Sciences, 29, 39-46.

[25] Maweru, S.C.Y. (2004) Current Initiatives on Microirrigation and Smallholder Markets in Malawi. Proceedings of Stakeholders' Experience and Lesson Sharing Workshop on Small Scale Irrigation and Market Development Held at 
Malawi Institute of Management (MIM), Lilongwe, 27-29 January 2004, 19-24.

[26] Kambewa, D. (2004) Patterns of Access and Use in Wetlands: Lake Chilwa Basin. Research Report to BASIS CRSP, Madison.

[27] FAO (1996) Socio-Economic and Production System Study of Wetland Use. Malawi Smallholder Irrigation Subsector Programme, Main Text and Working Paper 1.

[28] Matekere, E.C. and Lema, N.M. (2011) Performance Analysis of Public Funded Irrigation Projects in Tanzania. Irrigation Drainage Systems, 25, 237-253. http://dx.doi.org/10.1007/s10795-011-9119-9

[29] Le Gal, P., Rieu, T. and Fall, C. (2003) Water Pricing and Sustainability of Self-Governing Irrigation Schemes. Irrigation and Drainage Systems, 17, 213-238. http://dx.doi.org/10.1023/A:1025194513819

[30] Mul, M.L., Kemerink, J.S., Vyagusa, N.F., Mshana, M.G., van der Zaaga, P. and Makurira, H. (2011) Water Allocation Practices among Smallholder Farmers in the South Pare Mountains, Tanzania: The Issue of Scale. Agricultural Water Management, 98, 1752-1760. http://dx.doi.org/10.1016/j.agwat.2010.02.014

[31] Allen, R.G., Pereira, L.S., Raes, D. and Smith, M. (1998) Crop Evapotranspiration-Guidelines for Computing Crop Water Requirements-FAO Irrigation and Drainage Paper 56.

Rome.http://www.fao.org/docrep/X0490E/x0490e00.html

[32] Molden, D., Murray-Rust, H., Sakthivadivel, R. and Makin, I. (2003) A Water Productivity Framework for Understanding and Action. In: Kijne, J.W., Barker, R. and Molden, D., Eds., Water Productivity in Agriculture: Limits and Opportunities for Improvement, CAB International, Wallingford, 1-18.

[33] Mulinge, W.M., Thome, J.N. and Murithi, F.M. (2010) Impacts of Long-Term Terracing on Agricultural Water Management and Crop Productivity at Kaiti Catchment, Kenya. In: Mati, B.M., Eds., Agricultural Water Management Interventions Bearing Returns on Investment in Eastern and Southern Africa, IMAWESA Working Paper 17, $152-162$.

[34] Peters, P.E. (2004) Informal Irrigation in Lake Chilwa Basin: Stream Bank and Wetland Gardens. Research Report to BASIS CRSP, Madison.

[35] Ferguson, A.E. and Mulwafu, W.O. (2004) Irrigation Reform on Malawi’s Domasi and Likangala Smallholder Irrigation Schemes: Exploring Land-Water Intersections. Final Research Report to BASIS CRSP, Madison.

[36] Kamwamba-Mtethiwa, J., Namara, R., De Fraiture, C., Mangisoni, J. and Owusu, E. (2012) Treadle Pump Irrigation in Malawi: Adoption, Gender and Benefits. Irrigation and Drainage, 61, 583-595. http://dx.doi.org/10.1002/ird.1665

[37] Wiyo, K.A. and Kasomekera, Z.M. (1992) Study on Dambo Farming Communities in Malawi: Cash or Subsistence Farming? Bunda College of Agriculture, University of Malawi, Lilongwe, 157 p.

[38] Mloza-Banda, H.R., Banda, J.W., Lunduka, R. and Mohamoud, Y.M. (2001) The Dambo Ecosystems of the Diamphwe and Lilongwe River Catchments. I. Appraisal of Resources Availability and Use. UNISWA Research Journal of Agriculture, Science and Technology, 5, 49-59.

[39] Mloza-Banda, H.R., Banda, J.W., Lunduka, R. and Mohamoud, Y.M. (2001) The Dambo Ecosystems of the Diamphwe and Lilongwe River Catchments. II. Appraisal of Potential Indicators of Limits to Resource Availability and Use. UNISWA Research Journal of Agriculture, Science and Technology, 5, 148-158.

[40] Smith, M. (2000) Optimizing Crop Production and Crop Water Management under Reduced Water Supply. Food and Agricultural Organization, Rome, 20 p.

[41] Kamara, A.B., van Koppen, B. and Magingxa, L. (2002) Economic Viability of Small-Scale Irrigation Systems in the Context of State Withdrawal: The Arabie Scheme in the Northern Province of South Africa. Physics and Chemistry of the Earth, 27, 815-823. http://dx.doi.org/10.1016/S1474-7065(02)00070-0

[42] Mulwafu, W., Chipeta, C., Chavula, G., Ferguson, A., Nkhoma, B.G. and Chilima, G. (2003) Water Demand Management in Malawi: Problems and Prospects for Its Promotion. Physics and Chemistry of the Earth, 28, 787-796. http://dx.doi.org/10.1016/j.pce.2003.08.003

[43] Yokwe, S. (2009) Water Productivity in Smallholder Irrigation Schemes in South Africa. Agricultural Water Management, 96, 1223-1228. http://dx.doi.org/10.1016/j.agwat.2009.03.012

[44] Mulwafu, W.O. and Nkhoma, B.G. (2002) The Use and Management of Water in the Likangala Irrigation Scheme Complex in Southern Malawi. Physics and Chemistry of the Earth, 27, 839-844. http://dx.doi.org/10.1016/S1474-7065(02)00073-6

[45] Nangia, V., Turral, H. and Molden, D. (2008) Increasing Water Productivity with Improved N Fertilizer Management. Irrigation and Drainage Systems, 22, 193-207. http://dx.doi.org/10.1007/s10795-008-9051-9

[46] Turral, H., Svendsen, M. and Faures, J.M. (2010) Investing in Irrigation: Reviewing the Past and Looking to the Future. Agricultural Water Management, 97, 551-560. http://dx.doi.org/10.1016/j.agwat.2009.07.012

[47] Hanson, B.R., Schwankl, L.J., Schulbach, K.F. and Pettygrove, G.S. (1997) A Comparison of Furrow, Surface Drip, and Subsurface Drip Irrigation on Lettuce Yield and Applied Water. Agricultural Water Management, 33, 139-157. 
http://dx.doi.org/10.1016/S0378-3774(96)01289-9

[48] Bryla, D., Trout, T., Ayars, J. and Johnson, R. (2003) Growth and Production of Young Peach Trees Irrigated by Furrow, Microjet, Surface Drip, or Subsurface Drip Systems. Hort Science, 38, 1112-1116.

[49] Bryla, D., Dickson, E., Shenk, R., Johnson, R., Crisosto, C. and Trout, T. (2005) Influence of Irrigation Method and Scheduling on Patterns of Soil and Tree Water Status and Its Relation to Yield and Fruit Quality in Peach. Hort Science, 40, 2118-2124.

[50] Fandika, I.R., Kadyampakeni, D., Bottomani, C. and Kakhiwa, H. (2007) Comparative Response of Varied Irrigated Maize to Organic and Inorganic Fertilizer Application. Physics and Chemistry of the Earth, Parts A/B/C, 32, 11071116. http://dx.doi.org/10.1016/j.pce.2007.07.025

[51] Adeoti, A.I. (2009) Factors Influencing Irrigation Technology Adoption and Its Impact on Household Poverty in Ghana. Journal of Agriculture and Rural Development Tropics and Subtropics, 109, 51-63.

[52] Namara, R.E., Awuni, J.A., Barry, B., Giordano, M., Hope, L., Owusu, E.S. and Forkuor, G. (2011) Smallholder Shallow Groundwater Irrigation Development in the Upper East Region of Ghana. International Water Management Institute, Colombo, IWMI Research Report 143, 35 p. http://dx.doi.org/10.5337/2011.214

[53] Mangisoni, J.H. (2008) Impact of Treadle Pump Irrigation Technology on Smallholder Poverty and Food Security in Malawi: A Case Study of Blantyre and Mchinji Districts. International Journal of Agricultural Sustainability, 6, 248266. http://dx.doi.org/10.3763/ijas.2008.0306

[54] Kabutha, C., Blank, H. and van Koppen, B. (2000) Drip Irrigation Kits for Small-Holder Farmers in Kenya: Experience and Way Forward. 6th International Microirrigation Congress, Cape Town, 22-27 October 2000. 